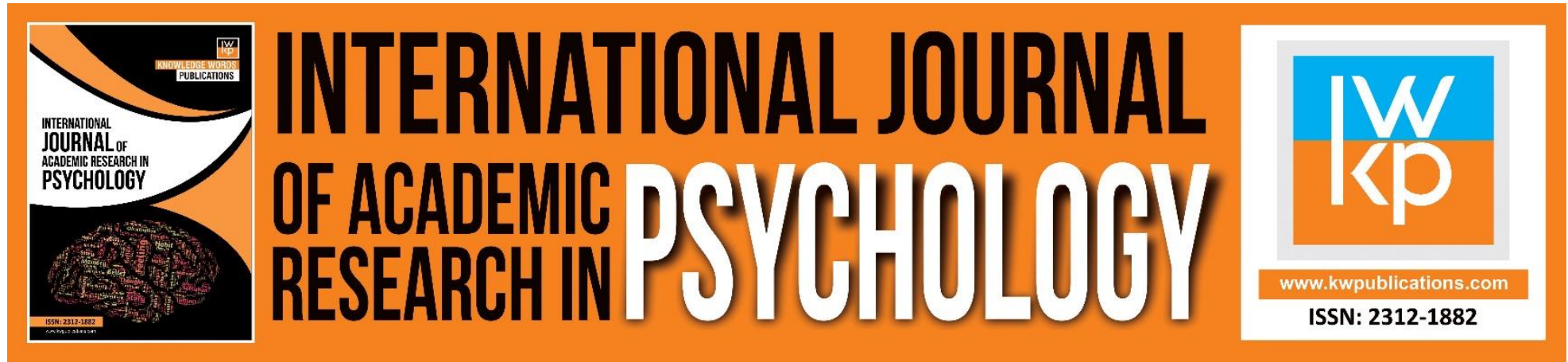

\title{
Relationship among Maltreatment Factors, PTSD Symptoms and Coping Strategies
}

\author{
Afshan Sabir, Saira Irfan
}

To Link this Article: http://dx.doi.org/10.46886/IJARP/v2-i1/1927

DOI: $10.46886 /$ IJARP/v2-i1/1927

Received: 16 October 2015, Revised: 12 November 2015, Accepted: 10 December 2015

Published Online: 26 December 2015

In-Text Citation: (Sabir \& Irfan, 2015)

To Cite this Article: Sabir, A., \& Irfan, S. (2015). Relationship among Maltreatment Factors, PTSD Symptoms and Coping Strategies. International Journal of Academic Research in Psychology. 2(1), 63-81.

\section{Copyright: (C) 2015 The Author(s)}

Published by Knowledge Words Publications (www.kwpublications.com)

This article is published under the Creative Commons Attribution (CC BY 4.0) license. Anyone may reproduce, distribute, translate and create derivative works of this article (for both commercial and non-commercial purposes), subject to full attribution to the original publication and authors. The full terms of this license may be seen

at: http://creativecommons.org/licences/by/4.0/legalcode

Vol. 2, No. 1, 2015, Pg. 63 - 81

https://kwpublications.com/journals/journaldetail/IJARP

JOURNAL HOMEPAGE

Full Terms \& Conditions of access and use can be found at https://kwpublications.com/pages/detail/publication-ethics 


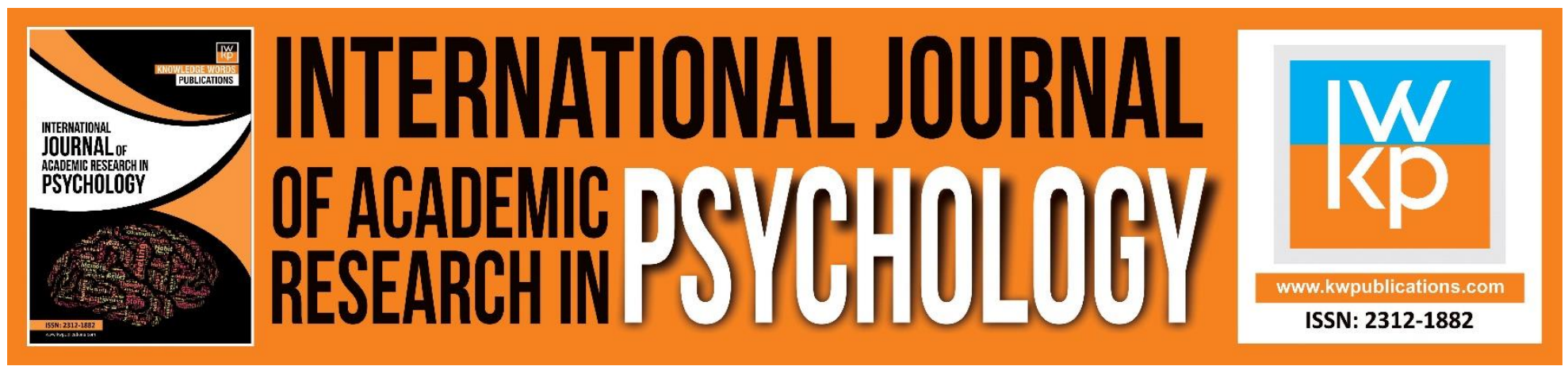

\title{
Relationship among Maltreatment Factors, PTSD Symptoms and Coping Strategies
}

\author{
Afshan Sabir \\ MS Student, Riphah International University, Lahore Campus, Pakistan
}

Saira Irfan

PhD Scholar, Lecturer Department of Applied Psychology, Bahauddin Zakariya University Campus,

Sahiwal, Pakistan

\begin{abstract}
There are hoisted rates of infancy abuse and posttraumatic stress disorder (PTSD) symptoms in abused females of shelter homes and old age homes. The current research intends to investigate the association among maltreatment factors, PTSD symptomatology and coping strategies. A survey research design was used in the study. The sample consisted of 150 participants, selected through purposive sampling technique.

Childhood trauma questionnaire (Bernstein \& Fink 1998), Davidson trauma scales (Davidson, 2003) and Brief cope scale (Carver, 1997) was used to assess the maltreatment factors, PTSD symptoms and coping strategies respectively. Descriptive statistics, correlation, One way ANOVA and Independent sample t-test were used to examine the data.

Results recommended significant relationship among maltreatment factors and PTSD symptomatology. Findings demonstrated a positive correlation between coping strategies and maltreatment factors. Results also indicated significant differences in relation to marital status, qualification, residence, area, and organizations. These findings postulated that childhood maltreatment is associated with the psychological disorder of PTSD symptomatology of re experiencing, avoidance or numbness and hyper-arousal and the maltreated women must use coping strategies after the abusive and neglected behavior. Findings suggest that child maltreatment is a predisposing feature for undesirable health effects in subsequent life and that coping strategies are critical components in this relationship. Suggestions for clinicians, medicinal experts, and specialists are examined.
\end{abstract}

Keywords: Maltreatment, PTSD, Coping Strategies, Shelter Homes, Old Age Homes.

Introduction

Childhood Maltreatment

Newspapers in 1876 tell the story of Mary Ellen Wilson, the first child in the United States 
being secured from an abusive situation. The first academic paper on child maltreatment was not published until 1962, after six years of Mary Ellen's death. The paper of Kemp in 1962 on Battered child syndrome introduces the new way for the study of child maltreatment and its results (Higgins, 2004). The Child Abuse Prevention and Treatment Act (CAPTA) passed in 1974. CAPTA devised broad legal definitions of child maltreatment, around physical and emotional harm, parental neglect and other harmful factors Of children's development (National Research Council, 1993; U.S. Department of Health and Human Services, 2005).

Maltreatment is defined as "actions that are abusive, neglectful or otherwise intimidating to the benefits of a child" (APA Committee on Professional Practice and Standards, 1998).

APA (1998) describes physical abuse as "the distress by a child and wide risk in which a child will suddenly suffer, a physical harm, imposed non-accidentally upon her/him by her/his parents or guardian "Sexual abuse is defined as "links between a child, an adult and another person significantly older or in a position of power or control on the child, where the child being used for sexual motivation of the adult or another person,"

Psychological neglect characterized as a rehashed model of conduct that express to kids that they are valueless, undesirable or just of worth in addressing another's necessities; may incorporate genuine dangers of physical and mental viciousness. Physical neglect is defined as "a child suffering from, or in substantial risk of physical harm causing defect, impairment of bodily functioning, or other serious physical injury as a result of situation created by a parent and other persons legally liable for the child's welfare, or by the failure of a parent or person legally responsible for the child's welfare to adequately supervise or protect him/her" (APA Committee on Professional Practice and Standards, 1998).

Neglect defined as "a lapse of care rather the charge of harm. Neglect has typically been identified through parent behavior or child experiences, which may change depending on developmental level and needs of the child (Dunn, 2002; \& Schumacher, et.al, 2001).

Emotional neglect includes an inability to give encouragement that must be given by near and dear ones. Consequently, it is imagined that a guardian psychologically ignores a child when he did not show up with love (Psychology Today Sussex Publishers).

\section{PTSD Symptomatology}

PTSD symptoms are that occurs in the result of maltreatment and abusive behavior. PTSD is characterized by the persistent experiencing of highly disturbing psychological symptoms that occur in reaction to trauma. DSM-V describes psychological symptoms associated with PTSD generally fall into three categories re-experiencing trauma (e.g. nightmares, flashbacks, or intrusive or recurrent thoughts), emotional avoidance (e.g. emotional numbing, avoidance of immediate stimuli, emotional numbing), and increased arousal (e.g., hyper vigilance, sleep disturbances, poor concentration). PTSD and chronic traumatization although the majority of the PTSD literature focuses primarily on individuals exposed to a specific, identifiable, one-time traumatic event, research has also started to examine the lasting impact of multi-time traumatic exposure, also known as chronic traumatization.

\section{Coping}

Coping strategies are "the coping style of a participant in stress situation" (Carver \& Scheier, 1981). 
Three coping strategies were used in this study, problem-focused coping, and emotion-focused coping and dysfunctional coping. Coping broadly defined as "relatively stable cognitive and behavioral techniques employed in an order to manage environmental stressors", (Moos \& Holahan, 2003). Generally speaking, coping involves both relatively stable styles and dispositions that depict an individual's characteristic ways of interacting with their environments in addition to the cognitive and behavioral responses or skills that they utilize to manage stressful encounters, (Moos \& Holahan, 2003). Coping involves biological, behavioral, cognitive, emotional, and social levels (Pearlin \& Schooler, 1978) and the coping strategies that any given individual utilizes rely on situational demands, (Folkman \& Gruen et al., 1986).

Some researchers characterized coping as falling into two discrete categories: problemfocused coping and emotion-focused coping (Folkman \& Lazarus, 1980; Folkman, \& Moskowitz, 2004; Lazarus \& Folkman, 1987). Problem-focused coping is defined as modifying the problematic personenvironment relationship. This type of coping includes engaging in effective, positive, purposeful, and adaptive, strategies that employ behavioral and cognitive techniques in an effort to actively alter the course of stress (e.g. seeking treatment or utilizing resources). On the contrary, emotion-focused coping refers to passive coping that involves utilizing negative, maladaptive, strategies that employ behavioral and cognitive techniques aimed at reducing emotional stress (e.g. avoidance, \& engaging in harmful behaviors) (Carver \& Scheier et al., 1989; Folkman \& Lazarus, 1980; Folkman \& Moskowitz, 2004; Moos \& Holahan, 2003).

More recently, it has been argued that the long-standing and extensively used categorization of coping strategies into problem-focused and emotion-focused could be expanded to include meaning-focused coping (Folkman \& Moskowitz, 2004), "a process of utilizing values and beliefs to modify the subjective meaning of stressful events, particularly those that are chronic or unavoidable", (Park \& Folkman, 1997).

Other investigations have conceptualized coping as either adaptive or maladaptive. Maladaptive coping is more often compared to emotion-focused coping and aims to diminish immediate anxiety but disturbs the later quality of life (Carver 1989). Examples of maladaptive coping include avoidance, venting, denial, and substance use, (Moos \& Schaefer., 1993). However, it should be noted though that although certain approaches are categorized as

"Maladaptive, these strategies may be adaptive for specific individuals or under certain circumstances. Adaptive coping, on the other hand, is similar to problem-focused coping and is designed to manage stress or solve a problem by eliminating or eradicating the stressor. (Dakof \& Taylor, 1990).

Evidence suggests that in high threat situations, both adaptive and maladaptive coping approaches are often engaged (Rippetoe \& Rogers, 1987). The literature does support the concept that a distinction exists between the effectiveness of each coping style with regard to future adjustment and psychological well-being. For example, research showed poorer adjustment was associated with specific forms of maladaptive coping including denial and avoidance (Carver et al., 1993).

\section{Literature Review}

Michelle, Terri \& David et al (2009) Childhood sexual abuse (CSA) has reliability been associated with the avoidant coping behavior, these coping methods and maltreatment factors tend to have a link with trauma symptoms which also linked to increasing the risk of adult sexual re- 
victimization. The purpose of this study was to test a model that based on the relationships among these variables. This model was tested in a cross-sectional study on a 99 females undergraduate college students having experienced CSA, who completed measures of abuse history, coping style, current levels of trauma symptoms and adult sexual re-victimization. Findings from this study suggested increased CSA severity has a link with avoidant coping which turn in greater levels of trauma symptoms while coping strategies and trauma and trauma symptoms were effective factors that place women at increased risk for coercive sexual re-victimization.

Tami \& Sullivan et al (1995) utilized path modeling to survey (a) the impact of youngster maltreatment on females' utilization of hostility and their encounters of being abused, (b) the relationship of these three variables to depressive and posttraumatic stress signs, and (c) the circuitous pathways from females confronting viciousness and their being abused to mental manifestations through escaping . Ladies' utilization of viciousness did not straightforwardly or by implication foresee symptomatology. Conversely, youngster misuse and ladies' encounters of being exploited were prescient of both depressive and posttraumatic stress manifestations, and being defrauded additionally were connected in a roundabout way to depressive side effects through avoidance coping.

Foster (2014) the study based on the experience of trauma among young adult college students that associated with symptoms of anxiety. Not only symptoms of anxiety associated to any trauma but sometimes there is a relationship were also found between individual level of coping either using adaptive coping rather than to maladaptive coping. Research has examined the interrelationship between the experience of trauma, specific types of coping and anxiety symptoms. A sample of 915 undergraduate students was selected. Results postulated that maladaptive coping, but not adaptive coping was a mediator of the association between the experience of trauma and symptoms of anxiety.

Walsh \& Fortier et al (2009) research in which coping was an important element to understand the long-term functioning of maltreated individuals such as sexual abuse. Research first examined the relation of coping theories with trauma and then examined that how these theories have been applied to studies of coping in sample of sexual abused individuals thirty nine studies were reviewed in which eleven descriptive studies with the history of sexually abuse, eighteen based on the relationship between coping strategies and ten investigated coping as meditational factors in relation to long term outcomes. These studies provide information that early sexual abuse relates to coping strategies.

\section{Rational of the Study}

The present study was conducted to find out the relationship among maltreatment factors, PTSD symptomatology and coping strategies in maltreated women. In Pakistan, different kinds of maltreatment has been increased alarmingly during the running years. These forms of maltreatment are associated with distinct, as well as shared, consequences. It was assumed that increased exposure to abuse increase the likelihood that the survivor will engage in coping strategies. In Pakistan there was numerous research on child maltreatment but not on maltreated women. This study investigated the childhood maltreatment and PTSD symptomatology in females. This research further examined the type of coping strategies used by maltreated women. PTSD symptoms occur due to maltreatment 
INTERNATIONAL JOURNAL OF ACADEMIC RESEARCH IN PSYCHOLOGY

Vol. 2, No. 1, 2015, E-ISSN: 2312-1882 @ 2015 KWP

that result in maladaptive coping. All forms of maltreatment are associated with developmental delays, health problem, and psychological disorders specially PTSD symptoms.

\section{Theoretical Framework}

Cognitive theories of PTSD based on memory models that define traumatic memories. According to these model in there are two memories one is an individual memory and other standard memories. Brewin, (2000) model in which a Dual depicted hypothesis based on 7 traumatic memories. In this model, two memories are parallel in capacity and one dominates the other on time. One framework is personal memory (verbal memory) based on recollections of traumatic events and second on the natural based on situational signals. In this framework the traumatic memory associated with other self-portraying recollections, it can be fully recovered when required and feelings also occur by the subjective exposure of those traumatic events.

Ehlers and Clark, (1999) postulate that while anxiety, in general, is a result of appraisals of an approaching threat; PTSD involves anxiety about the future although the traumatic event leading to PTSD already has happened. They recommended that traumatic events will give rise to PTSD when individuals process information from the event in a way that leads to a sense of current threat. The model emphasizes the way in which stimulus are practice during trauma.

\section{Coping Theories}

Coping is characterized as a procedure of "continually changing subjective and behavioral endeavors to manage particular outer and/or inward requests that are assessed as exhausting or surpassing the resources of the individual. There are two types of adapting: Problem-focused coping utilized when we feel we have control over the circumstance, subsequently can manage the cause of the issue. There are four stages to deal with this anxiety: 1.Define the issue, 2. Produce elective arrangements, 3. Learn new aptitudes to managing stressors, 4. Reappraise and find new benchmarks of conduct. Emotion-focused coping utilized when an individual feels as though they can't deal with the root cause of the issue. It includes picking up methodologies for managing anxiety. 1. Maintaining a strategic distance from (I am not going to school), 2. Removing (yourself from the anxiety, 'it doesn't make a difference'), 3. Acknowledgment (I fizzled that exam, yet I have 4 different subjects), 4. Looking for Medical Support, 5. Using liquor.

\section{Objectives}

1) To determine a relationship between childhood maltreatment and PTSD symptomatology.

2) To examine the relationship between coping strategies and maltreatment factors.

3) To investigate differences in childhood maltreatment, PTSD symptomatology and coping on the bases of demographic variables.

\section{Hypothesis}

1) There would be significant relationship among childhood maltreatment and PTSD symptoms and coping.

2) There would be significant differences in childhood maltreatment, PTSD symptoms and coping on the basis of demographic variables. 
INTERNATIONAL JOURNAL OF ACADEMIC RESEARCH IN PSYCHOLOGY

Vol. 2, No. 1, 2015, E-ISSN: 2312-1882 @ 2015 KWP

\section{Method}

\section{Sample}

The sample comprised of 150 maltreated women between the ages 18 to 65 was selected through purposive sampling from shelter homes and old age homes of Lahore, Sahiwal, and Pakpttan.

Table 1

Demographic aspects of Total Sample $(N=150)$

\begin{tabular}{|c|c|c|}
\hline Variables & Frequency & Percentage \\
\hline \multicolumn{3}{|l|}{ Age } \\
\hline $18-29$ & 61 & 40.7 \\
\hline $30-41$ & 49 & 32.7 \\
\hline $42-53$ & 27 & 18.0 \\
\hline $54-65$ & 13 & 8.7 \\
\hline \multicolumn{3}{|l|}{ Marital Status } \\
\hline Single & 24 & 16.0 \\
\hline Married & 67 & 44.7 \\
\hline Divorced & 32 & 21.3 \\
\hline Widowed & 27 & 18.0 \\
\hline \multicolumn{3}{|l|}{ Residence } \\
\hline Homeless & 112 & 74.7 \\
\hline Home & 38 & 25.3 \\
\hline \multicolumn{3}{|l|}{ Qualification } \\
\hline Illiterate & 39 & 26.0 \\
\hline Primary & 33 & 22.0 \\
\hline Middle & 10 & 6.7 \\
\hline F.A & 17 & 11.3 \\
\hline Graduation & 21 & 14.0 \\
\hline Master & 04 & 2.7 \\
\hline \multicolumn{3}{|l|}{ Job Status } \\
\hline Unemployed & 109 & 72.7 \\
\hline Employed & 41 & 27.3 \\
\hline \multicolumn{3}{|l|}{ Area } \\
\hline Rural & 76 & 50.7 \\
\hline Urban & 74 & 49.3 \\
\hline
\end{tabular}

Instruments

Childhood Trauma Questionnaire - Short Form (CTQ) by Bernstein \& Fink, (1995). The CTQ was chosen to measure the construct of childhood maltreatment, the independent variable of this study. It is based on 28 items, self-report measure of the childhood maltreatment, using 5-point Likert scale 1 (never true) to 5 (very often true). Five dependent factors of childhood maltreated women sexual abuse, physical abuse, emotional abuse; physical neglect and emotional neglect were assessed by summing each subset. 
Davidson Trauma Scale (DTS) by Davidson, (2003). The scale DTS used as dependent variable is a 17item self-report measure that assesses both severity and frequency PTSD symptomatology experienced over the course of the previous week using five point-Likert scale. By summing both severity and frequency subscale showed the criterion B, C, D scoring. Items 1-4 and 17 relate to criterion $B$ (intrusive re-experiencing), item 5-11 related to criterion C (avoidance and numbness) and item 12-16 related to criterion D (hyper-arousal) of Post-Traumatic Stress Disorder.

Brief Cope Scale (B-Cope) by Carver,(1997) used as dependent variable it is self-reported inventory consisted on 28 items that contain 14 separate scales and statements are rated on 4 point Likert rating scales from 0 as "I haven't been doing this all" to "I have been doing this a lot." Scoring of three coping types includes problem-focused coping, emotion-focusing coping, and dysfunctional coping were obtained by summing for the items in each subscale, with higher scores indicating greater use of that type of coping

\section{Procedure}

The data were collected from shelter homes and old age homes. The demographic variable sheet was used to collect the bio data from each respondent. Respondents fill the Childhood trauma questionnaire, Brief cope scale, and Davidson trauma scale. Respondents were informed about confidentiality issue. All these measures were examined by using Statistical Package for Social Sciences (SPSS, version 20.0).

\section{Results}

The present study was conducted to investigate the relationship among childhood maltreatment and post-traumatic stress disorder symptomatology and coping in abused women. The data comprised of 150 maltreated women of sheltered homes and old age homes examined and analyzed the in the light of the goals of the study.

Descriptive statistics was applied to depict scales averages and standard deviation and alpha reliability coefficients. Pearson correlation coefficient was applied to investigate the relationship among the variables. Then t-test and one-way analysis of variance was performed to measure variance in Childhood Trauma Questionnaire, Davidson Trauma Scale and Brief Cope in relation to the demographic variables such as age, qualification, marital status and cities. 
INTERNATIONAL JOURNAL OF ACADEMIC RESEARCH IN PSYCHOLOGY

Vol. 2, No. 1, 2015, E-ISSN: 2312-1882 @ 2015 KWP

Table 2

Pearson correlation of Childhood Maltreatment and PTSD Symptomatology.

\begin{tabular}{lllllllll}
\hline Scales & P.Abuse & E.Abuse & S.Abuse & P.neglect & E.neglect & Criterion.B & Criterion.C & Criterion.D \\
\hline P.Abuse & 1 & $.230^{* *}$ & .073 & $.243^{* *}$ & -.081 & .066 & .145 & .046 \\
E.Abuse & & 1 & -.090 & $.458^{* *}$ & -.085 & -.004 & .128 & .117 \\
S.Abuse & & & 1 & -.004 & $.178^{*}$ & .085 & .109 & -.077 \\
P.neglect & & & 1 & -.077 & .133 & .160 & $.181^{*}$ \\
E.neglect & & & & 1 & .091 & .110 & -.045 \\
Criterion.B & & & & & 1 & $.440^{* *}$ & $.283^{* *}$ \\
Criterion.C & & & & & & 1 & .128 \\
Criterion.D & & & & & & & & 1 \\
\hline
\end{tabular}

Note:P.neglect means physical neglect and criterion D shows hyper-arousal symptoms.

Table 2 showed a correlation between maltreatment and PTSD symptomatology. In this table, results illustrate a correlation between physical neglect and criterion. D $r=.18^{*}$ that shows the PTSD symptoms of hyper-arousal.

\section{Table 3}

Pearson correlation of maltreatment and coping strategies

\begin{tabular}{lllllllll}
\hline Scales & P.F.Coping & E.F.Coping & D.Coping & P.Abuse & E.Abuse & S.Abuse & P.neglect & E.neglect \\
\hline P.F.Coping & 1 & .120 & .019 & $.177^{*}$ & .100 & .085 & $.220^{* *}$ & $.189^{*}$ \\
E.F.Coping & 1 & .027 & .016 & .091 & .043 & .034 & .065 \\
D.Coping & & 1 & -.054 & $-.301^{* *}$ & .118 & -.022 & .093 \\
P.Abuse & & & 1 & $.230^{* *}$ & .073 & $.243^{* *}$ & -.081 \\
E.Abuse & & & & 1 & -.090 & $.458^{* *}$ & -.085 \\
S.Abuse & & & & & 1 & -.004 & $.178^{*}$ \\
P.neglect & & & & & & & 1 & -.077 \\
E.neglect & & & & & & & .349 \\
\hline
\end{tabular}

Table 3 shows a correlation between maltreatment and coping strategies. This table shows relationship of Problem-Focused Coping (P. F) with physical abuse (P. abuse) $r=.177^{*}$, also correlated with Emotional neglect .189*. Problem-focusing coping with Physical neglect (P. N) $r=.22 * *$ that showed a strongly positive correlation. Denial coping showed strongly negative correlation with Emotional Abuse $-.301^{* *}$. 
INTERNATIONAL JOURNAL OF ACADEMIC RESEARCH IN PSYCHOLOGY

Vol. 2, No. 1, 2015, E-ISSN: 2312-1882 @ 2015 KWP

\section{Table 4}

One Way ANOVA variance test of maltreatment, PTSD symptoms and coping strategies on the basis of Marital Status.

\begin{tabular}{|c|c|c|c|c|c|c|}
\hline Scales & source & SS & Df & MS & $F$ & $\mathrm{~F}$ \\
\hline \multirow{3}{*}{ P.F.Coping } & $\begin{array}{l}\text { Between } \\
\text { Groups }\end{array}$ & 4.678 & 3 & 1.559 & 2.588 & .055 \\
\hline & $\begin{array}{l}\text { Within } \\
\text { Groups }\end{array}$ & 87.962 & 146 & .602 & & \\
\hline & Total & 92.640 & 149 & & & \\
\hline \multirow{3}{*}{ E.F.Coping } & $\begin{array}{l}\text { Between } \\
\text { Groups }\end{array}$ & 2.497 & 3 & .832 & 1.033 & .380 \\
\hline & $\begin{array}{l}\text { Within } \\
\text { Groups }\end{array}$ & 117.643 & 146 & .806 & & \\
\hline & Total & 120.140 & 149 & & & \\
\hline \multirow{3}{*}{ D.Coping } & $\begin{array}{l}\text { Between } \\
\text { Groups }\end{array}$ & 2.269 & 3 & .756 & .585 & .626 \\
\hline & $\begin{array}{l}\text { Within } \\
\text { Groups }\end{array}$ & 188.804 & 146 & 1.293 & & \\
\hline & Total & 191.073 & 149 & & & \\
\hline \multirow{3}{*}{ P.Abuse } & $\begin{array}{l}\text { Between } \\
\text { Groups }\end{array}$ & 3.579 & 3 & 1.193 & .658 & .579 \\
\hline & $\begin{array}{l}\text { Within } \\
\text { Groups }\end{array}$ & 264.714 & 146 & 1.813 & & \\
\hline & Total & 268.293 & 149 & & & \\
\hline \multirow{3}{*}{ E.Abuse } & $\begin{array}{l}\text { Between } \\
\text { Groups }\end{array}$ & 5.510 & 3 & 1.837 & .861 & .463 \\
\hline & $\begin{array}{l}\text { Within } \\
\text { Groups }\end{array}$ & 311.323 & 146 & 2.132 & & \\
\hline & Total & 316.833 & 149 & & & \\
\hline \multirow{3}{*}{ S.Abuse } & $\begin{array}{l}\text { Between } \\
\text { Groups }\end{array}$ & 6.779 & 3 & 2.260 & 1.333 & .266 \\
\hline & $\begin{array}{l}\text { Within } \\
\text { Groups }\end{array}$ & 247.494 & 146 & 1.695 & & \\
\hline & Total & 254.273 & 149 & & & \\
\hline \multirow{3}{*}{ P.neglect } & $\begin{array}{l}\text { Between } \\
\text { Groups }\end{array}$ & .775 & 3 & .258 & .194 & .901 \\
\hline & $\begin{array}{l}\text { Within } \\
\text { Groups }\end{array}$ & 194.698 & 146 & 1.334 & & \\
\hline & Total & 195.473 & 149 & & & \\
\hline E.neglect & $\begin{array}{l}\text { Between } \\
\text { Groups }\end{array}$ & 16.793 & 3 & 5.598 & 3.756 & .012 \\
\hline
\end{tabular}


INTERNATIONAL JOURNAL OF ACADEMIC RESEARCH IN PSYCHOLOGY

Vol. 2, No. 1, 2015, E-ISSN: 2312-1882 @ 2015 KWP

\begin{tabular}{|c|c|c|c|c|c|c|}
\hline & $\begin{array}{l}\text { Within } \\
\text { Groups } \\
\text { Total }\end{array}$ & $\begin{array}{l}217.581 \\
234.373\end{array}$ & $\begin{array}{l}146 \\
149\end{array}$ & 1.490 & & \\
\hline \multirow{3}{*}{ Criterion.B } & $\begin{array}{l}\text { Between } \\
\text { Groups }\end{array}$ & .333 & 3 & .111 & .153 & .928 \\
\hline & $\begin{array}{l}\text { Within } \\
\text { Groups }\end{array}$ & 106.360 & 146 & .728 & & \\
\hline & Total & 106.693 & 149 & & & \\
\hline \multirow{3}{*}{ Criterion.C } & $\begin{array}{l}\text { Between } \\
\text { Groups }\end{array}$ & .119 & 3 & .040 & .089 & .966 \\
\hline & $\begin{array}{l}\text { Within } \\
\text { Groups }\end{array}$ & 65.381 & 146 & .448 & & \\
\hline & Total & 65.500 & 149 & & & \\
\hline \multirow{3}{*}{ Criterion.D } & $\begin{array}{l}\text { Between } \\
\text { Groups }\end{array}$ & .097 & 3 & .032 & .035 & .991 \\
\hline & $\begin{array}{l}\text { Within } \\
\text { Groups }\end{array}$ & 136.976 & 146 & .938 & & \\
\hline & Total & 137.073 & 149 & & & \\
\hline
\end{tabular}

Table 4 One-way ANOVA was administered to observe differences of maltreatment, PTSD Symptoms and coping strategies on the bases of marital Status. There was a significant difference only in Emotional neglect scores on for the four marital status groups $F(3,146)=3.75,(.012), p<.05$.

In statistical significance, the real difference in mean score was little but its show somehow differences in means and Sd. The impact size was found by using eta squared that was .07.post- hoc examination using the Tukey HSD test that illustrate the mean scores for Group1( $\mathrm{m}=62.95, \mathrm{Sd}=$ 1.30) was not same as Group 4 ( $m=61.85$, Sd .76) Group 2 and 3 did not vary fundamentally from either group 1 or 4. 
INTERNATIONAL JOURNAL OF ACADEMIC RESEARCH IN PSYCHOLOGY

Vol. 2, No. 1, 2015, E-ISSN: 2312-1882 @ 2015 KWP

Table 5

One Way ANOVA variance test of maltreatment, PTSD symptoms and coping strategies on the basis of education.

\begin{tabular}{|c|c|c|c|c|c|c|}
\hline Scales & Source of Variance & SS & $D f$ & $M S$ & $F$ & $P$ \\
\hline \multirow{3}{*}{ P.F.Coping } & Between Groups & 1.798 & 6 & .300 & .472 & .829 \\
\hline & Within Groups & 90.842 & 143 & .635 & & \\
\hline & Total & 92.640 & 149 & & & \\
\hline \multirow{3}{*}{ E.F.Coping } & Between Groups & 1.950 & 6 & .325 & .393 & .882 \\
\hline & Within Groups & 118.190 & 143 & .827 & & \\
\hline & Total & 120.140 & 149 & & & \\
\hline \multirow{3}{*}{ D.Coping } & Between Groups & 9.050 & 6 & 1.508 & 1.185 & .318 \\
\hline & Within Groups & 182.023 & 143 & 1.273 & & \\
\hline & Total & 191.073 & 149 & & & \\
\hline \multirow{3}{*}{ P.Abuse } & Between Groups & 26.028 & 6 & 4.338 & 2.561 & .022 \\
\hline & Within Groups & 242.265 & 143 & 1.694 & & \\
\hline & Total & 268.293 & 149 & & & \\
\hline \multirow{3}{*}{ E.Abuse } & Between Groups & 31.854 & 6 & 5.309 & 2.664 & .018 \\
\hline & Within Groups & 284.979 & 143 & 1.993 & & \\
\hline & Total & 316.833 & 149 & & & \\
\hline \multirow{3}{*}{ S.Abuse } & Between Groups & 19.321 & 6 & 3.220 & 1.960 & .075 \\
\hline & Within Groups & 234.952 & 143 & 1.643 & & \\
\hline & Total & 254.273 & 149 & & & \\
\hline \multirow{3}{*}{ P.neglect } & Between Groups & 27.185 & 6 & 4.531 & 3.850 & .001 \\
\hline & Within Groups & 168.288 & 143 & 1.177 & & \\
\hline & Total & 195.473 & 149 & & & \\
\hline \multirow{3}{*}{ E.neglect } & Between Groups & 16.266 & 6 & 2.711 & 1.777 & .108 \\
\hline & Within Groups & 218.108 & 143 & 1.525 & & \\
\hline & Total & 234.373 & 149 & & & \\
\hline \multirow{3}{*}{ Criterion. B } & Between Groups & 2.076 & 6 & .346 & .473 & .828 \\
\hline & Within Groups & 104.618 & 143 & .732 & & \\
\hline & Total & 106.693 & 149 & & & \\
\hline \multirow{3}{*}{ Criterion.C } & Between Groups & 5.137 & 6 & .856 & 2.028 & .066 \\
\hline & Within Groups & 60.363 & 143 & .422 & & \\
\hline & Total & 65.500 & 149 & & & \\
\hline \multirow{3}{*}{ Criterion.D } & Between Groups & 6.349 & 6 & 1.058 & 1.158 & .332 \\
\hline & Within Groups & 130.724 & 143 & .914 & & \\
\hline & Total & 137.073 & 149 & & & \\
\hline
\end{tabular}

Table 5 One way ANOVA was administered to examine difference of maltreatment, PTSD Symptoms and coping on the bases of Education. There was significant differences were found in, Emotional 
abuse $F(6,143)=2.66,(.018), P<.05$, Physical neglect $F(6,143)=3.85(.001) P<.05$ and criterion $C F$ $(6,143)=2.02(.066) p<.05$ scores on for the 7 groups of education.

In statistical significance, real difference in mean scores was found. The impact size was found by using eta squared that was 0.10 . post hoe using the Tukey HSD test that illustrate the mean scores for Group 1 illiterate ( $m=83.12$, Sd.1.50) was not same and showed difference with Group 5 F.A (m $=81.88, \mathrm{Sd} 1.11)$ on the bases of Emotional Abuse while Group1 illiterate $(\mathrm{m}=31.43, \mathrm{Sd} .96)$ showed difference with Group 4 metric $(m=30.57$, Sd 1.17), Group 6 graduation $(m=30.42, S d 1.12)$ and Group 7 master ( $m=29.50$, Sd.57) , group 2, group3, group5 were not vary either group1,4,6 and group 7.

Table 6

One Way ANOVA variance test of maltreatment, PTSD symptoms and coping strategies on the basis of Cities

\begin{tabular}{|c|c|c|c|c|c|c|}
\hline $\begin{array}{l}\text { Scales } \\
\text { variance }\end{array}$ & Source of & SS & Df & MS & $\mathrm{F}$ & $P$ \\
\hline \multirow{3}{*}{$\begin{array}{l}\text { P.F.Copin } \\
\mathrm{g}\end{array}$} & Between Groups & 2.430 & 2 & 1.215 & 1.980 & 142 \\
\hline & Within Groups & 90.210 & 147 & .614 & & \\
\hline & Total & 92.640 & 149 & & & \\
\hline \multirow{3}{*}{$\begin{array}{l}\text { E.F.Copin } \\
\text { g }\end{array}$} & Between Groups & 1.605 & 2 & .802 & .995 & .372 \\
\hline & Within Groups & 118.535 & 147 & .806 & & \\
\hline & Total & 120.140 & 149 & & & \\
\hline \multirow{3}{*}{ D.Coping } & Between Groups & 3.833 & 2 & 1.916 & 1.504 & .226 \\
\hline & Within Groups & 187.241 & 147 & 1.274 & & \\
\hline & Total & 191.073 & 149 & & & \\
\hline \multirow{3}{*}{ P.Abuse } & Between Groups & 39.023 & 2 & 19.512 & 12.510 & .000 \\
\hline & Within Groups & 229.270 & 147 & 1.560 & & \\
\hline & Total & 268.293 & 149 & & & \\
\hline \multirow{3}{*}{ E.Abuse } & Between Groups & 27.798 & 2 & 13.899 & 7.069 & .001 \\
\hline & Within Groups & 289.035 & 147 & 1.966 & & \\
\hline & Total & 316.833 & 149 & & & \\
\hline \multirow{3}{*}{ S.Abuse } & Between Groups & 12.236 & 2 & 6.118 & 3.716 & .027 \\
\hline & Within Groups & 242.037 & 147 & 1.647 & & \\
\hline & Total & 254.273 & 149 & & & \\
\hline \multirow{3}{*}{ P.neglect } & Between Groups & 25.159 & 2 & 12.579 & 10.857 & .000 \\
\hline & Within Groups & 170.314 & 147 & 1.159 & & \\
\hline & Total & 195.473 & 149 & & & \\
\hline \multirow{3}{*}{ E.neglect } & Between Groups & 2.468 & 2 & 1.234 & .782 & .459 \\
\hline & Within Groups & 231.905 & 147 & 1.578 & & \\
\hline & Total & 234.373 & 149 & & & \\
\hline Criterion. & Between Groups & .969 & 2 & .484 & .674 & .511 \\
\hline B & Within Groups & 105.724 & 147 & .719 & & \\
\hline
\end{tabular}


INTERNATIONAL JOURNAL OF ACADEMIC RESEARCH IN PSYCHOLOGY

Vol. 2, No. 1, 2015, E-ISSN: 2312-1882 @ 2015 KWP

\begin{tabular}{|c|c|c|c|c|c|c|}
\hline & Total & 106.693 & 149 & & & \\
\hline \multirow{3}{*}{$\begin{array}{l}\text { Criterion. } \\
\text { C }\end{array}$} & Between Groups & 1.812 & 2 & .906 & 2.091 & .127 \\
\hline & Within Groups & 63.688 & 147 & .433 & & \\
\hline & Total & 65.500 & 149 & & & \\
\hline \multirow{3}{*}{$\begin{array}{l}\text { Criterion. } \\
\text { D }\end{array}$} & Between Groups & 1.659 & 2 & .830 & .901 & .409 \\
\hline & Within Groups & 135.414 & 147 & .921 & & \\
\hline & Total & 137.073 & 149 & & & \\
\hline
\end{tabular}

In this table, One Way ANOVA was administered to examine the difference between maltreatment, PTSD symptoms and coping strategies on the bases of cities. By statistical way mean scores were different, $F(2,147)=12.57,(.000) p<.05$, the impact size was 0.1 , Group 3 Pakpattan $(\mathrm{m}$ $=61.72$, Sd 1.06) altogether different with group 1 Sahiwal $(m=60.73, \mathrm{Sd} 1.32$ and group 2 Lahore $(\mathrm{m}=60.50, \mathrm{Sd} 1.30)$ in maltreatment factors of Physical abuse.

The mean scores were different $F(2,147)=7.069$, $(.001) p<.05$, impact size was .08, group 3 Pakpattan ( $m=61.72$, Sd 1.35) was different with group 1 and group 2 in Emotional Abuse.

The mean scores were different $F(2,147)=3.71$, (.027) $p<.05$, impact size was .04, group 1 ( $m=91.90, \mathrm{Sd} 1.35)$ showed significant difference with group $3(\mathrm{~m}=92.67, \mathrm{Sd} 1.09)$ in maltreatment factor of sexual abuse.

The mean scores were different $F(2,147)=10.85$, (.000) $p<.05$, impact size was 0.1 , group 3 $(\mathrm{m}=31.47$, Sd.98) was different from group 1 and group 3 while group 1 and 3 not vary each other.

\section{Table 7}

Levene's Independent sample t-test of maltreatment, PTSD symptomatology and coping strategies on the basis of Job Status.

\begin{tabular}{|c|c|c|c|c|c|c|c|c|}
\hline \multicolumn{9}{|c|}{ Maltreated women $(n=150)$} \\
\hline \multirow[t]{2}{*}{ Variable } & \multicolumn{2}{|c|}{ Unemployed } & \multicolumn{2}{|c|}{ Employed } & \multirow[t]{2}{*}{$\mathrm{t}$} & \multirow[t]{2}{*}{$p$} & \multirow[t]{2}{*}{$95 \% \mathrm{Cl}$} & \multirow[t]{2}{*}{ Cohen's c } \\
\hline & $\mathrm{M}$ & SD & $\mathrm{M}$ & SD & & & & \\
\hline P.neglecte & 31.03 & 1.03 & 30.34 & 1.27 & 3.121 & .003 & {$[-.79,17]$} & 0.59 \\
\hline
\end{tabular}

Note: P. neglect=Physical neglect

Table 6 Leven's independent sample t-test was administered to examine differences of maltreatment factors, PTSD symptoms and coping on the bases of Job Status. The physical neglect factor shows significant value .006 , select second line of table, $t=3.121$, df 60.86, 2 tailed significant value was .003 , unemployed with mean score $(\mathrm{m}=31.03, \mathrm{Sd} 1.03)$ and employed mean score $(\mathrm{m}=$ $30.34, \mathrm{Sd} 1.27)$ with moderated effect size of physical neglect on job status.

\section{Table 8}

Leven's Independent Sample t test of scales on the basis of Area

\begin{tabular}{|c|c|c|c|c|c|c|c|c|}
\hline \multicolumn{9}{|c|}{ Maltreated women $(n=150)$} \\
\hline \multirow[t]{2}{*}{ Variable } & Rural & & Urban & & $\mathrm{t}$ & $\mathrm{p}$ & $95 \% \mathrm{Cl}$ & Cohen's d \\
\hline & M & SD & M & SD & & & & \\
\hline P.neglect & 31.65 & 1.05 & 30.63 & 1.20 & 2.26 & 0.25 & {$[.05, .78]$} & 0.90 \\
\hline
\end{tabular}

Note: P.neglect=Physical neglect 
INTERNATIONAL JOURNAL OF ACADEMIC RESEARCH IN PSYCHOLOGY

Vol. 2, No. 1, 2015, E-ISSN: 2312-1882 @ 2015 KWP

In table 7 Leven's independent sample t test was administered to examine the differences in scales on the bases of Area. The physical neglect factor of maltreatment shows significant value .01, after selecting the second line of table, $t=2.263$, df 148, 2 tailed significant value 0.25 , that showed Rural with mean score $(m=31.05, \mathrm{Sd} 1.05)$ and Urban mean score $(\mathrm{m}=30.63, \mathrm{Sd} 1.20)$ with moderating effect size of physical neglect on the bases of area.

\section{Discussion}

Maltreatment continuously increased during the last decades in Pakistan, maltreated women also suffered from PTSD symptomatology after the intense abusive behavior. They may adopt PTSD symptoms after maltreatment in childhood which became long-lasting years by years.

Previous researches also showed the significant relation between maltreatment and PTSD symptoms, childhood history of physical-emotional abuse or sexual-emotional abuse was initiated to be significantly related to current PTSD symptomatology. Statistically significant positive correlations existed between the physical- emotional abuse childhood maltreatment component and current PTSD symptomatology, as well as between the sexual-emotional abuse childhood maltreatment component and current PTSD symptomatology. The positive correlation between the neglect childhood maltreatment component and current PTSD symptomatology was not statistically significant.

The present study results illustrated a significant relationship between five factors of maltreatment and PTSD symptomatology in maltreated women of shelter homes and old age home. The results of this study showed significant correlation between the physical neglect factors of maltreatment with criterion D that shows the PTSD symptomatology of hyperarousal. In this study results showed that through physical neglect the symptoms of hyperarousal have more chance to occur.

Some previous researches showed the relationship of some factors of maltreatment with current PTSD symptomatology, one of previous research illustrate link between both physical-sexual abuse and current PTSD symptomatology and sexual-emotional abuse and PTSD symptomatology are consistent with evidence from a number of studies that have found that physically and sexually abused children may be at increased risk for developing PTSD in adulthood (Schaaf \& McCanne, 1998; Widom, 1999).

Results showed that women faced physical abuse and emotional neglect in childhood adopt the problem-focused coping strategy and women with physical neglect adopt in more amount of this coping strategy. Denial coping strategy used those who faced emotional abuse in childhood.

Coping relationship with factors of maltreatment also examined in this research that showed which maltreatment factors correlate with coping strategies. A history of child maltreatment was associated with increased emotion-focused coping and physical abuse and sexual abuse defined link with problem focused coping and also with dysfunctional coping (Gall, 2006; Runtz \& Schallow, 1997).

In another study coping strategies were also showed positive relationship between child maltreatment and physical health status (Hgerr, McGill University, 2006) which investigated the mediating influence of problem-focused coping. This study showed results that there is a correlation between coping strategies and five factors of maltreatment. Strong correlations were found between several variables of Problem-solving coping positively correlated with both physical abuse and sexual abuse, (Stephen \& Long, 1999). 
Demographic variables of age, marital status, residence, education, job status, area, organization were used in this study in order to determine differences with maltreatment, PTSD symptomatology, and coping strategies. However, difference did not show with age variable while marital status showed significant differences with study variables.

The results showed differences in maltreatment factors and PTSD symptoms on the basis of qualification. According to Maria (1990) finding, showed differences in the groups of qualification illiterate and graduation on the basis of physical abuse. According to these findings the women who faced a great deal of emotional abuse as a child were illiterate or less educated while women who did graduation and master had less physical neglect. Physical neglect was found greater in illiterate women as compared to educated females, which shows as the maltreatment increases educational achievement decreases.

Exposure to one or more types of maltreatment may result in an array of negative outcomes, including lower academic achievement. Children exposed to maltreatment are at increased risk of educational underachievement, including lower verbal and math scores (National Children Advocacy Center, 2013).

The analysis showed significant differences on the basis of marital status in four groups. According to this study results, single women had a history of emotional neglection as compared to widow women while married and divorced women had the same amount of emotional neglection with widow one.

In these finding results about cities showed that women of Pakpattan city faced higher amount of physical abuse, emotional abuse and physical neglect as compared to Sahiwal and Lahore while the amount of Sexual abuse found in less amount in sahiwal's women as compared to other cities. The second hypothesis was there would be significant differences between maltreatment, PTSD symptoms and coping strategies which accepted after analysis. In another finding maltreated women showed a difference on the basis of cities, the amount of abusive behavior and coping strategies were different as their cities were changed (Hobfoll, 1989).

\section{Acknowledgement}

All praise is for ALLAH, the most Merciful and His Prophet Muhammad (P.B.U.H) for guiding me, giving me insight and protecting me throughout the whole process and for giving me extra strength, without His mercy and protection I could not have done anything.

I owe a deep sense of gratitude to my respected supervisor Mam Saira Irfan, for her keen interest on me at every stage of my research. Her prompt inspiration, timely suggestions with kindness, enthusiasm and dynamism has enabled me to complete my thesis. I also got confidence and enriching my knowledge by her devoted support in my thesis project. I am particularly grateful to my parents who supporting me in this work.

\section{Corresponding Author}

Saira Irfan, Ph.D Scholar, Lecturer, Department of Applied Psychology, Bahauddin Zakariya University, Sub Campus Sahiwal, Pakistan. Email: sairamukhtar@gmail.com 
INTERNATIONAL JOURNAL OF ACADEMIC RESEARCH IN PSYCHOLOGY

Vol. 2, No. 1, 2015, E-ISSN: 2312-1882 @ 2015 KWP

\section{References}

American Psychiatric Association. (2000). Diagnostic and statistical manual of mental disorders (5 ed.). Washington, DC: American Psychology Publishing.

American Psychological Association Committee on professional practice and standards. (1998). Guidelines for psychological evaluation in child protection matters.

Brewin, C. R., Andrews, B., \& Valentine, J. D. (2000). Meta-analysis of risk factors for posttraumatic stress disorder in trauma-exposed adults.

Bernstein, D. P., \& Fink, L. (1998). Childhood Trauma Questionnaire: A retrospective self-report. San Antonio, TX: Harcourt, Brace, and Company.

Carver, C. S. (1997). The Brief COP [measurement scale]. International journal of Behavioural Medicine, 4, 92- 100.

Carver, C. S., \& Scheier, M. F. (1981). Attention and self-regulation: A control theory approach to human behavior. New York: Springer-Verlag.

Carver, C. S., Scheier, M. F., \& Weintraub, J. K. (1989). Assessing coping strategies: A theoretically based approach. Journal of Personality and Social Psychology, 56, 267-283.

Dunn, E. S. (2009). Childhood maltreatment and adult post-traumatic stress disorder symptomatology in abused, suicidal, low-income, African American women.

Davidson, J. (2003). Davidson Trauma Scale. North Tonawanda, NY: Multi-Health Systems Inc.

Dunn, M. G., Tarter, R. E., Mezzich, A. C., Vanyukov, M., Kirisci, L., \& Kirillova, (2002). G. Origins and consequences of child neglect in substance abuse families. Clinical Psychology Review. 22, 1063-1090.

Dakof, G. A., \& Taylor, S. E. (1990). Victim's perceptions of social support: What is helpful from whom? Journal of Personality and Social Psychology, 58, 80-89.

Ehlers, A., \& Clark. (1999). PTSD symptoms, response to intrusive memories, and coping in ambulance service workers. British Journal of Clinical Psychology, 38, 251-265.

Folkman, S., \& Lazarus, R. S. (1980). If it changes it must be a process: The study of emotion and coping during three stages of a college examination. Journal of Personality and Social Psychology, 48, 150-170.

Folkman, S., Lazarus, R. S., Dunkel-Schetter, C., DeLongis, A., \& Gruen, R. J. (1986). The dynamics of a stressful encounter: Cognitive appraisal, coping, and encounter outcomes. Journal of Personality and Social Psychology, 50, 992-1003.

Folkman, S., \& Moskowitz, J. T. (2004). Coping: Pitfalls and promise. Annual Review of Psychology, $55,745-774$.

Foster, A. (2014). Traumatic life events and symptoms of anxiety: Moderating effects of adaptive Versus maladaptive coping strategies. Electronic Theses and Dissertations, Paper 2380. Retrieved from http://dc.etsu.edu/etd/2380.

Fortier, A. M., DiLillo, D., Messman-Moore, L. T., Peugh. J., DeNardi, A. K., and Gaffey, J. K. (2009). Severity of Child Sexual Abuse and Revictimization: The Mediating Role of Coping and Trauma Symptoms. (2009). Published in Psychology of Women Quarterly 33:3 (2009), pp. 308-320. Retrieved from DigitalCommons@University of Nebraska - Lincoln: http://digitalcommons.unl.edu/psychfacpub/400.

Gall, T. L. (2006). Spirituality and coping with life stress among adult survivors of childhood sexual abuse. Child Abuse and Neglect. 30, 829-844. 
INTERNATIONAL JOURNAL OF ACADEMIC RESEARCH IN PSYCHOLOGY

Vol. 2, No. 1, 2015, E-ISSN: 2312-1882 @ 2015 KWP

Higgins, D. J. (2004). The importance of degree versus the type of maltreatment: A cluster analysis of child abuse types. Journal of Psychology: Interdisciplinary and Applied, 138, 303-324

Hobfoll, S. E. (1989). Conservation of resources: A new attempt at conceptualizing stress. American Psychologist, 44 (3), 513-524.

Hagger, D. A., Alanna, B. A. (2006). An Investigation of the Perceived Stress, Coping Strategies, and Physical Health of Childhood Maltreatment Survivors. McGill University, https://dspace.library.uvic.ca/bitstream/handle/1828/2021.

Lazarus, R. S., \& Folkman, S. (1987). Transactional theory and research on emotions and coping. European Journal of Personality, 1, 141-169.

Moos, R. H., \& Holahan, C. J. (2003). Dispositional and contextual perspectives on coping: Towards an integrative framework. Journal of Clinical Psychology, 59, 1387-1403.

Moos, R., H., \& Schaefer, J. A. (1993). Coping resources and processes: Current concepts and measures.

National Children Advocacy Center. (2013). The relationship between child maltreatment and academic achievement. Retrieved from http://mha.ohio.gov/Portals/0/assets/Initiatives/TIC/ChildrenYouthAdolescents.

National Research Council. (1993). Understanding Child Abuse and Neglect. National Academy Press, Washington, DC.

Park, C. L., \& Folkman, S. (1997). Meaning in the context of stress and coping. Review of General Psychology, 1, 115-144.

Pearlin, L. L., \& Schooler, C. (1978). The structure of coping. Journal of Health and Social Behavior, 19, 2-21. Psychological Bulletin, 129, 216-269.

Runtz. \& Schallow. (1997). Social support and coping strategies as mediators of adult adjustment following childhood maltreatment. Journal of Child Abuse \& Neglect, Volume 21, Pages 211-226.

Rippetoe, P. A., \& Rogers, R. W. (1987). Effects of components of protective-motivation theory on adaptive and maladaptive coping with a health threat. Journal of Personality and Social Psychology, 52, 596-604.

Schaaf, K. K., \& McCanne, T. R. (1998). Relationship of childhood sexual, physical, and combined sexual and physical abuse to adult victimization and posttraumatic stress disorder. Child Abuse and Neglect, 22, 1119-1113.

Stephens, C. V., \& Long, N. (1999). Posttraumatic stress disorder in the New Zealand police: The moderating role of social support following traumatic stress. Anxiety, Stress, and Coping, 12, 247-265.

Schumacher, J. A., Slep, S. A. M., \& Heyman, R. E. (2001). Risk factors for child neglect. Aggression and Violent Behavior, 6, 231-254.

Tami, P. Sullivan., Katharine, J. Meese., Suzanne, C. Swan., Carolyn, M. Mazure., and David, L. Snow. (1995). Department of Psychiatry, Yale University School of Medicine.

U.S. Department of Health and Human Services, A. O. C., Youth, and Families. (2005). Child maltreatment (2005). Washington, DC: Government Printing Office.

U.S. Department of Health and Human Services. (2002). Child maltreatment 2002: Reports from the states to the national child abuse and neglect data system. Washington DC: U.S. Government Printing Office. 
U.S. Department of Health and Human Services: Administration on Children, Youth, \& Families. (2008). Child maltreatment. (2006). Washington DC: Government Printing Office.

Widom, C. S. (1999). Posttraumatic stress disorder in abused and neglected children grown up. American Journal of Psychiatry, 156, 1223-1229.

Walsh, K., Fortier, M. A., and Dilillo, D. (2009). Adult coping with childhood sexual abuse: A theoretical and empirical review. Faculty Publication, Department of Psychology. Paper 396. http://digital commons.unl.edu/psychfacpub/396. 